\title{
Analysis of the Avoidance of Nitrogen Fertilizers in the Water Column by Juvenile Iberian Water Frog, Pelophylax perezi (Seoane, 1885), in Laboratory Conditions
}

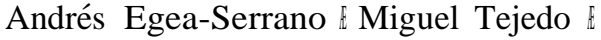 \\ Mar Torralva
}

\begin{abstract}
In an experiment carried out in the laboratory in beakers, the avoidance of ammonium chloride, isolated or combined with sodium nitrite and sodium nitrate, in aquatic habitat by froglets of Pelophylax perezi was studied. The results obtained suggest that nitrogen polluted treatments were not avoided by froglets of the studied species. However, despite the non-avoidance of the aquatic environment as a consequence of the presence of nitrogen compounds, significant inter-individual variation in treatment avoidance was detected. Although these results are not conclusive, they would suggest that froglets of P. perezi might occupy habitats which contain high levels of organic compounds and that they differ in their level of avoidance to fertilizer exposure.
\end{abstract}

Keywords Nitrogenous compounds Treatment avoidance Pelophylax perezi Postmetamorphic individuals

Fertilizer pollution has been described as one of the major factors threatening amphibian populations throughout the world (Stuart et al. 2004). Both aquatic and terrestrial amphibian phases are vulnerable to nitrogen excess in their environments (Hatch et al. 2001; Marco et al. 2001; Ortiz et al. 2004; Griffis-Kyle 2007). Ammonium chloride and

\footnotetext{
A. Egea-Serrano (\&) M. Torralva

Departamento de Zoología y Antropología Física, Facultad de

Biología, Universidad de Murcia, 30100 Murcia, Spain

e-mail: aegea@um.es

M. Tejedo

Departamento de Biología Evolutiva, Estación Biológica

Doñana-CSIC, Avda, María-Luisa s/n, Pabellón del Perú,

41013 Sevilla, Spain
}

sodium nitrate are nitrogen compounds used as fertilizer (Bhandari et al. 1971; Graebing et al. 2002) since they are a source of ammonium and nitrate. The presence of these ions in water may increase nitrite concentration as a consequence of bacterial activity (Atlas and Bartha 2002). All three forms of nitrogen have been shown to negatively (Jofre and Karasov 1999; Schuytema and Nebeker 1999; Griffis-Kyle 2007) or positively, by way of algal proliferation (Boone et al. 2007) affect the survival, growth, and development of amphibian embryos and larvae. Nevertheless, no study has been performed on the effects of their excess on postmetamorphic amphibians in spite of the great importance that postmetamorphic stages may have on amphibian population dynamics, as it has been previously suggested (Biek et al. 2002). Previous studies have shown that amphibians with an adult terrestrial phase can detect fertilizers in their environment and avoid them (Hatch et al. 2001; Marco et al. 2001; Ortiz-Santaliestra et al. 2005). However, as regards species that use aquatic or semiaquatic habitats during their postmetamorphic stages as shelter from predators (Martín et al. 2006), for foraging (Docampo and Vega 1990) and as breeding habitat (Egea-Serrano et al. 2005), the possible avoidance of such habitats as a response to fertilizer exposure has not been assessed.

Moreover, in natural conditions fertilizers combine with other stressing factors (UV-B radiation, nitrogen compounds, and pesticides) and so exposure to such a cocktail may modify the response in a non-additive way (Brown and Spence 2003). However, to date most studies have examined the effects of individual contaminants on amphibians (Storfer 2003) and, although some studies have assessed the effects of a combination of fertilizers and other pollutants (Brown and Spence 2003; Orton et al. 2006), none has attempted to determine the effects nitrogen compound mixtures have on amphibian behavior. 
The aim of the present study was to determine whether the presence of a high concentration of ammonium chloride, isolated or combined with sodium nitrite and sodium nitrate, in the water column was avoided by postmetamorphic Pelophylax perezi. This anuran is an endemic water frog species from the Iberian Peninsula and Southern France (Llorente and Arano 1997). It mainly inhabits permanent waterbodies (Diaz-Paniagua 1990), from which adults disperse $\backslash 5 \mathrm{~m}$, although juveniles and subadults may move greater distances (Lizana et al. 1989). Because such environments, as a result of farming practices (one of the main nitrogen sources in the environment, e.g. Ritter and Bergstrom 2001), may hold high concentrations of nitrogenous compounds (e.g. for southeastern Iberian Peninsula: $154.6 \mathrm{mg} / \mathrm{L} \mathrm{NH} \mathrm{NH}_{4}^{+}, 74.4 \mathrm{mg} / \mathrm{L} \mathrm{NO}-$, $333 \mathrm{mg} / \mathrm{L}$ $\mathrm{NO}_{3}^{-}$, Suárez, personal communication) which may affect mortality and the behavior of larval P. perezi (Egea-Serrano, unpublished data), this species might be threatened by organic pollution, since it uses waterbodies as shelter from predators (Martín et al. 2006), for foraging (Docampo and Vega 1990) and as breeding habitat (Egea-Serrano et al. 2005). However, although it has been described as being very tolerant to organic pollution (Llorente et al. 2002), no studies analyzing the specific effects that nitrogen compounds may have on P. perezi have been published.

\section{Material and Methods}

Five different egg masses of P. perezi were collected from a natural population exposed to a low level of nitrogen pollution ( $5.1 \mathrm{mg} \mathrm{N}-\mathrm{NO}_{3}^{-} / \mathrm{L}$ (Vidal-Abarca et al. 2000)) in the Segura River basin (U.T.M. 30SXH). This basin, which covers an area of $14,432 \mathrm{~km}^{2}$ in the Southeastern Iberian Peninsula, has been described as one of the most arid zones of the Iberian Peninsula (Vidal-Abarca et al. 1987) and, probably, Europe (Geiger 1973). A trend towards eutrophication of waterbodies in this basin, which comprises ponds, streams, and tributaries of the main Segura River where P. perezi breeds, has been described (Vidal-Abarca et al. 1990; Ballester 2003).

Eggs were reared in the laboratory in $12 \mathrm{~L}$ aquaria, at roughly $23-25^{\circ} \mathrm{C}$, in aerated dechlorinated tap water until larvae reached the Gosner 25 developmental stage (Gosner 1960). Then they were individually transferred to clear, food-quality, 1-L plastic beakers containing $500 \mathrm{~mL}$ of dechlorinated tap water. The water in the beakers was renewed every 3 days to prevent oxygen depletion. The larvae were fed every 3 days with dry dog chow pellets (250-350 mg). They reached the Gosneŕs 46 developmental stage (Gosner 1960) after 71-97 days (snout-vent length (mean $\pm 1 \mathrm{SE}$ ): $16.47 \pm 0.53 \mathrm{~mm}, \mathrm{n}=24$ ). Just after reaching this developmental stage, froglets were individually transferred to $1 \mathrm{~L}$ plastic beakers containing $100 \mathrm{~mL}$ of one of the following treatments: (1) $0 \mathrm{mg} / \mathrm{L}$ (control), (2) $40 \mathrm{mg} / \mathrm{L} \mathrm{NH}_{4} \mathrm{Cl}$, (3) $40 \mathrm{mg} / \mathrm{L} \mathrm{NH} 4 \mathrm{Cl}+500$ $\mathrm{mg} / \mathrm{L} \quad \mathrm{NaNO}_{3}+100 \mathrm{mg} / \mathrm{L} \quad \mathrm{NaNO}_{2}$, (4) $40 \mathrm{mg} / \mathrm{L}$ $\mathrm{NH}_{4} \mathrm{Cl}+500 \mathrm{mg} / \mathrm{L} \mathrm{NaNO}_{3}+10 \mathrm{mg} / \mathrm{L} \mathrm{NaNO}_{2}$. Neither eggs nor larvae were exposed to these treatments. Treatments were selected because they were observed to reduce larval survival in the aquatic phase of the studied species (Egea-Serrano, unpublished data) and because the concentrations are representative of the high ammonium, nitrite and nitrate levels detected in watercourses of the Segura River basin (e.g. $154.6 \mathrm{mg} / \mathrm{L} \quad \mathrm{NH}_{4}^{+}, 74.4 \mathrm{mg} / \mathrm{L}$ $\mathrm{NO}_{2}^{-}, 333 \mathrm{mg} / \mathrm{L} \mathrm{NO}-$, Suárez, personal communication). Ammonium, nitrite and nitrate solutions were prepared from $\mathrm{NH}_{4} \mathrm{Cl}, \mathrm{NaNO}_{2}$, and $\mathrm{NaNO}_{3}$, respectively. Each beaker was randomly assigned to one of the above treatments. Treatments 1 and 3 were replicated seven times, whereas treatments 2 and 4 were replicated five times due to differences in larval survival up to metamorphosis between treatments. Although water quality was not measured in this experiment, previous tests performed under identical conditions showed that water conductivity and salinity are significantly higher in all treatments exposed to fertilizers than the control treatment (conductivity: $F_{3,54}=3413.769$, $p=0.0001$; salinity: $F_{3,54}=1340.024$, $\mathrm{p}=0.0001) . \mathrm{pH}$ showed significant differences among treatments $\left(\mathrm{F}_{3,54}=2.878, \mathrm{p}=0.044\right)$. Nevertheless, a post hoc multiple comparison test did not confirm the existence of such differences (Tukey's test: p [ 0.122, in all cases). No significant differences among treatments were detected in relation to water temperature $\left(F_{3,54}=0.324, p=0.808\right)$

The water in the beakers was completely renewed and the fertilizer level restored daily. The beakers were tightly closed to avoid water evaporation, ammonium volatization and the escape of any specimen. They were tilted $\left(10^{\circ}\right.$, approximately) so that half of the floor of each beaker was submerged and the other half completely dry. Froglets were observed twice daily (at $12 \mathrm{~h}$ intervals) over a 14-day period. Each experimental unit was observed for $30 \mathrm{~s}$, recording whether the froglets were resting on the submerged half or on the emerged half (including walls) of the beakers. Observations were made at a distance of at least $1 \mathrm{~m}$ from the experimental units to avoid disturbing the animals. Although froglets were fed ad libitum with flightless fruitflies, none of them ate during the duration of the experiment. No froglet died during the exposure time.

To determine whether the treatments used in the present study were avoided by the studied species, four separate statistical approaches were performed. First, to study the temporal variation during the 2 weeks the experiment lasted (weekly analysis) one-way repeated measures ANCOVA was used, with the number of censuses in which 

froglets were found in the submerged half of the beakers on each week of the experiment as dependent variable. Second, to assess the circadian variations in treatment avoidance (circadian analysis), one-way repeated measures ANCOVA was used, with the number of censuses in which froglets were found in the submerged half of the beakers in the mornings and evenings the experiment included as dependent variable. Third, to obtain an overall view (global analysis) of treatment avoidance by froglets, one-way ANCOVA was used, with the number of censuses in which froglets were found in the submerged half of the beakers over the 2 weeks the experiment lasted. For these three statistical analyses, the treatment was considered as independent variable and snout-vent length at metamorphosis as the covariate. Finally, the inter-individual variation in treatment avoidance was studied. Variable treatment avoidance (dependent variable) was coded as a binary variable ( 1 , froglets on the emerged half of the beakers or on their walls; 2, froglets in the submerged half of the beakers), and differences between individuals (single factor: individual froglet) for each treatment was analysed using Kruskal-Wallis test. Additionally, repeatability (r) for each treatment was calculated using the methodology proposed by Lessells and Boag (1987). Data were transformed logarithmically $(\log x ; \log (x+1)$ in the case of the circadian analysis). Previous statistical analyses were performed using SPSS ${ }^{\circledR}$ statistical package version 11.0 and a significant level of 5\% was selected. Additionally, a power analysis was performed on number of censuses in which froglets were detected in the submerged half of the beakers during either the first and the second week of the experiment, mornings and evenings included in the experiment and, finally, over the 2 weeks the experiment lasted using STATISTICA 6.0 statistical package (Statsoft Inc. 2001). Since STATISTICA only performs power analyses when each group of the studied parameters shows an identical number of cases, we haphazardly selected the cases so that all treatments showed the same number of cases $(n=5)$. Root-mean-square error from each logarithmically transformed variable and a significant level of $5 \%$ was used.

\section{Results and Discussion}

The treatments were not avoided by P. perezi froglets as observed from weekly and circadian analyses (Table 1, Fig. 1). The global analysis showed that the presence of organic compounds in the aquatic environment does not imply its avoidance by froglets of the studied species $\left(F_{3,18}=0.124, p=0.945\right)$ (Table 1$)$. In spite of these results, a significant interaction between treatment and time was detected in relation to the circadian analysis (Fig. 1).
Although power was very low for all analyses performed (Table 1), the high p-values exhibited by the treatment effect (p โ0.76 in all cases) suggested no support for the hypothesis concerning an effect of pollutant treatments on the avoidance response of froglets (Table 1, Fig. 1).

Froglets exposed to treatment 1 or control showed significant inter-individual variation as regards treatment avoidance $\left(v_{6}^{2}=44.465, p=0.0001\right)$, and the highest repeatability of all treatments $(r=0.32)$. Likewise, a significant effect of the individual on treatment avoidance was detected in the case of treatments $3\left(\mathrm{v}_{6}^{2}=28.538\right.$, $\mathrm{p}=0.0001, \mathrm{r}=0.23)$ and $4\left(\mathrm{v}_{4}^{2}=12.858, \mathrm{p}=0.012\right.$, $\mathrm{r}=0.11)$. Individuals exposed to treatment 2 showed no significant variation in treatment avoidance $\left(\mathrm{v}_{4}^{2}=5.776\right.$, $\mathrm{p}=0.217)$ and the lowest repeatability of all treatments $(\mathrm{r}=0.023)$.

Although the power of the analyses performed was low, the results obtained suggest that none of the nitrogen-polluted treatments was avoided by postmetamorphic froglets

Table 1 Summary statistics for the one-way repeated measures ANCOVA (weekly and circadian analysis) and one-way ANCOVA (global analysis) on treatment avoidance by froglets of P. perezi

\begin{tabular}{lccc}
\hline Source of variation & df & F & p \\
\hline $\begin{array}{l}\text { Weekly analysis (first week: } \\
\text { Between subjects effects }\end{array}$ & 3 & 0.207 & 0.891 \\
Treatment & 1 & 1.299 & 0.269 \\
SVL & & & \\
Within subjects effects & 1 & 0.294 & 0.594 \\
Time & 3 & 0.046 & 0.986 \\
Time 9 treatment & 1 & 0.290 & 0.597 \\
Time 9 SVL & 18 & & \\
Error &
\end{tabular}

Circadian analysis (mornings: 0.16; evenings: 0.16)

Between subjects effects

$\begin{array}{llll}\text { Treatment } & 3 & 0.392 & 0.760 \\ \text { SVL } & 1 & 2.525 & 0.129\end{array}$

Within subjects effects

$\begin{array}{llll}\text { Time } & 1 & 3.527 & 0.077 \\ \text { Time } 9 \text { treatment } & 3 & 4.727 & 0.013 \\ \text { Time } 9 \text { SVL } & 1 & 3.393 & 0.082\end{array}$

Error $\quad 18$

Global analysis (global: 0.056)

Between subjects effects

$\begin{array}{lrrr}\text { Treatment } & 3 & 0.124 & 0.945 \\ \text { SVL } & 1 & 1.184 & 0.291 \\ \text { Error } & 18 & & \end{array}$

SVL: snout-vent length. The result of the power analysis on the number of censuses in which froglets were detected in the submerged half of the beakers during the first and the second week of the experiment, mornings and evenings included in the experiment and over the 2 weeks that the experiment lasted is presented in brackets 

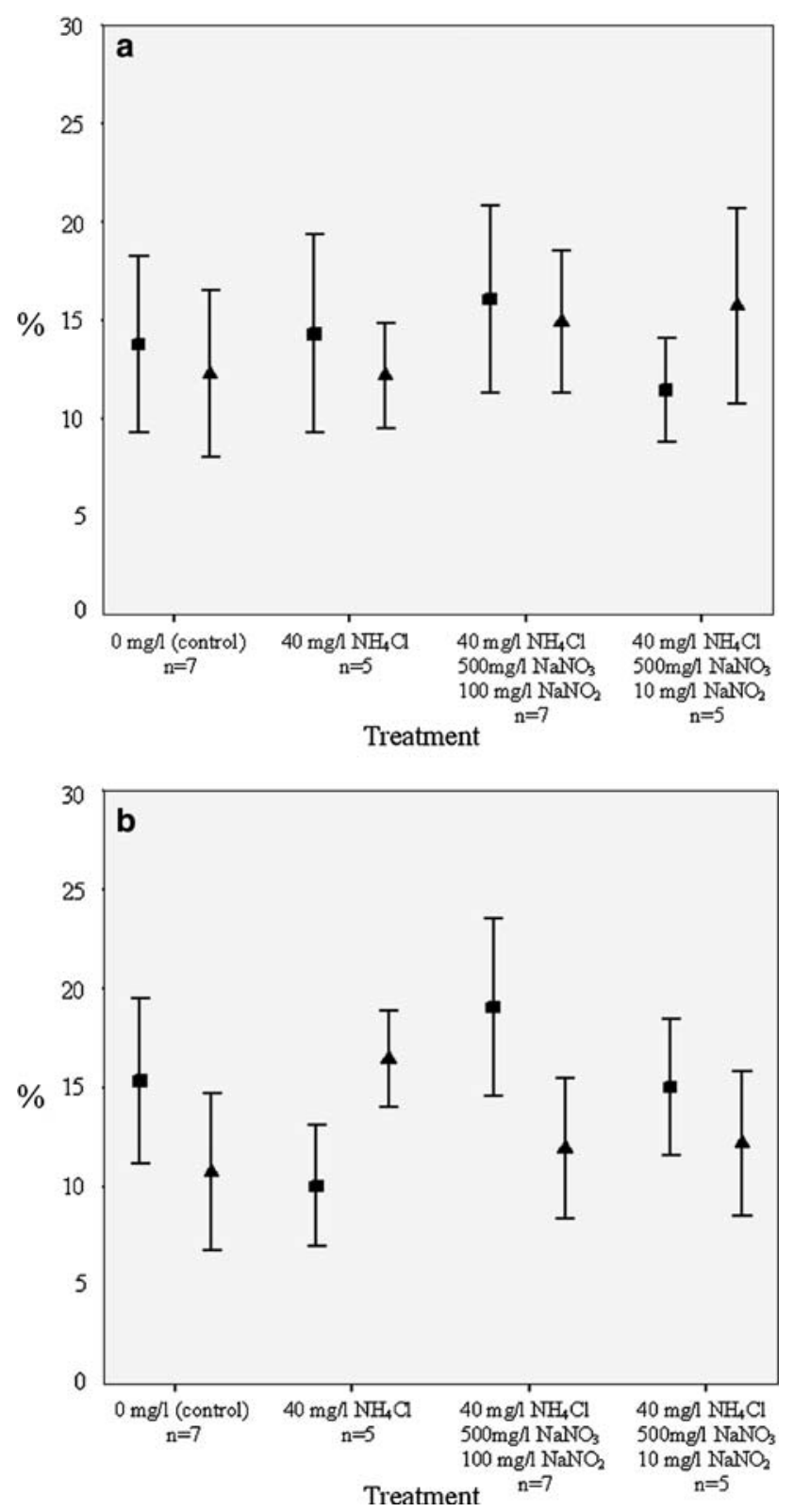

Fig. 1 Mean proportion ( \pm 1 SE) of number of times metamorphic individuals were detected in contact with the different nitrogen water treatments for (a) weekly analysis ( $\mathbf{j}$ first week of the experiment, $m$ second week of the experiment) and (b) circadian analysis ( $\mathbf{j}$ mornings, m evenings)

of P. perezi. Given that these treatments correspond to the high ammonium, nitrite and nitrate concentrations that actually occur in the Segura River basin (Suárez, personal communication), we can predict that ecologically relevant levels of eutrophication may not influence habitat use by the studied species. This highly aquatic frog uses the aquatic environment as shelter from predators (Martín et al. 2006), as well as for foraging (Docampo and Vega 1990) and breeding (Egea-Serrano et al. 2005). This absence of any effect of organic concentration on habitat selection suggests that froglets are able to use the highly stressful concentrated organic habitat in spite of the detrimental consequence that this absence of avoidance may have on survival or reproductive success (Oldham et al. 1997; Hatch et al. 2001; Marco et al. 2001; Ortiz-Santaliestra et al. 2005). Nevertherless, the significant interindividual variation in treatment avoidance, with associated moderate repeatability values, indicates that individual froglets may differ in their level of avoidance to fertilizer exposure. This could well have important effects at a populational scale since repeatability is associated with heritability placing an upper bound on heritability and thus to the potential to adapt to these stressful polluted environments (Falconer 1989).

Previous studies have shown that different amphibian species avoid high fertilizer concentrations in their terrestrial environment in the laboratory (Hatch et al. 2001; Marco et al. 2001; Ortiz-Santaliestra et al. 2005) and that the combination of pollutants may produce a multiplicative rather than an additive response (Brown and Spence 2003). However, the present results suggest that postmetamorphic froglets of P. perezi do not exhibit an avoidance response to single and combined fertilizer stressors. Marco et al. (2001) suggested that the vulnerability of amphibian postmetamorphic stages to fertilizers could be due to nitrogen uptake through their permeable skin. In aquatic and semiaquatic anurans, pulmonary ventilation is more important than cutaneous gas exchange and, as a consequence, their skin is less vascularized than that of terrestrial anurans (Duellman and Trueb 1994). Considering the aquatic habits of P. perezi (Lizana et al. 1989), its cutaneous vascularization may not be highly developed, which would make its skin scarcely permeable. So, these characteristics may confer a certain degree of tolerance to fertilizers. In addition, Hatch et al. (2001) attributed the non-avoidance of high urea concentration in soil substrate by juvenile Bufo boreas to the stress that toads could have experienced during the experiment, which may have prevented them from detecting such concentration. Ammonium can be transformed into ammonia, a toxic nitrogen compound for amphibians (Jofre and Karasov 1999), which can volatilize (Ritter and Bergstrom 2001), entering the amphibians through the skin and lungs. Although treatments were renewed daily, it is possible that the beakers containing the fertilizer treatments accumulated an ammonia concentration sufficiently high to stress the froglets, preventing them from detecting the presence of fertilizers and from avoiding them. Taking into account these considerations, the lack of habitat avoidance could be explained by both a species tolerance to fertilizers as well as by a sublethal response to them. Thus, no conclusive explanation can be provided. Given that a species may avoid low fertilizer concentrations but not higher levels 
(Hatch et al. 2001), future research considering fertilizer concentrations differing from those employed in the present study are needed to determine whether P. perezi is tolerant to fertilizers or whether it can detect and avoid their presence in the environment.

The general avoidance of water by froglets detected in the present study is of note. Taking into consideration that the beakers were closed, this result cannot be attributed to toxic fumes from surrounding beakers which could affect all froglets. On the contrary, this avoidance could be explained by considering the results presented by Lizana et al. (1989), who described that postmetamorphic individuals are forced to disperse from ponds where they developed. So, although a more specific study on habitat selection by postmetamorphic P. perezi has not been performed and, consequently, any explanation would be hypothetical, this result might suggest that froglets avoid water even in laboratory conditions as a consequence of an endogenous trend to disperse to land, as it occurs in the wild (Lizana et al. 1989). This consideration emphasizes the relevance of developing future studies about treatment avoidance with adult P. perezi to test whether this developmental stage is more aquatic than the juvenile stage and whether it is more affected by the presence of nitrogenous compounds in the water.

Finally, it must be noted that it is difficult to generalize to the field the results obtained from laboratory experiments. This study suggests that nitrogen pollution has no influence on the habitat use of P. perezi froglets. Nevertheless, considering that the substrate can affect fertilizer avoidance behavior (Hatch et al. 2001), and that permanent waterbodies inhabited by this species (Díaz-Paniagua 1990), as well as the soil surrounding them, may be polluted by the presence of different nitrogenous compounds, pesticides and their degradates, the behavior of the studied species in the field could differ significantly from the results presented in this work. So, studies representing a more realistic approach to natural conditions are indispensable for assessing the actual impact fertilizer pollution has on P. perezi habitat use.

Acknowledgments We thank Dr. María Luisa Suárez for her comments on eutrophication levels in the Segura River basin. Michelle D. Boone and one anonymous referee read and improved the manuscript, and also merit our gratitude. We acknowledge the Environmental Service of the Autonomous Government of Murcia, Spain, for providing the permits to collect the biological material used in this study. This work was supported by a Caja de Ahorros del Mediterráneo predoctoral fellowship to A. Egea-Serrano.

\section{References}

Atlas RM, Bartha R (2002) Ecología microbiana y microbiología ambiental. Pearson Educación SA. Addison Wesley, Madrid
Ballester R (dir) (2003) Los humedales de la Región de Murcia: Humedales y ramblas de la Región de Murcia. Dirección General del Medio Natural-Región de Murcia, Murcia

Bhandari GS, Singh L, Gupta US (1971) Effect of different concentrations of some ammonium fertilizers on the germination of Pennisetum typhoides Stapf \& Hubb. and Sorghum vulgare Pers. Plant Soil 34:229-232

Biek R, Funk WC, Maxell BA, Scott L (2002) What is missing in amphibian decline research insights from ecological sensitivity analysis. Conserv Biol 16:728-734

Boone MD, Semlitsch RD, Little EE, Doyle MC (2007) Multiple stressors in amphibian communities: effects of chemical contamination, bullfrogs, and fish. Ecol Appl 17:291-301

Brown K, Spence KM (2003) Effects of sublethal concentrations atrazine and nitrate on metamorphosis of the African clawed frog. Environ Contam Toxicol 22:627-635

Díaz-Paniagua C (1990) Temporary ponds as breeding site of amphibians at a locality in Southwestern Spain. Herpetol J 1:447-453

Docampo L, Vega MM (1990) Contribución al estudio de la alimentación de Barbus bocagei (Steindachner, 1866), Phoxinus phoxinus (Linnaeus, 1758) y Rana perezi (Seoane, 1885) en ríos de Bizkaia. Scientia Gerundensis 16:61-73

Duellman WE, Trueb L (1994) Biology of amphibians. The Johns Hopkins University Press, Baltimore

Egea-Serrano A, Oliva-Paterna FJ, Torralva M (2005) Selección de hábitat reproductor por Rana perezi Seoane, 1885 en el NO de la Región de Murcia (SE Península Ibérica). Rev Esp Herpetol 19:113-125

Falconer DS (1989) Introduction to quantitative genetics. Longman, Harlow

Geiger F (1973) El sureste español y los problemas de la aridez. Revista de Geografía VII:166-209

Gosner KL (1960) A simplified table for staging anuran embryos and larvae with notes on identification. Herpetologica 16:183190

Graebing P, Frank M, Chib JS (2002) Effects of fertilizer and soil components on pesticide photolysis. J Agric Food Chem 50:7332-7339

Griffis-Kyle KL (2007) Sublethal effects of nitrite on eastern tiger salamander (Ambystoma tigrinum tigrinum) and wood frog (Rana sylvatica) embryos and larvae: implications for field populations. Aquat Ecol 41:119-127

Hatch AC, Belden LK, Scheessele E, Blaustein AR (2001) Juvenile amphibians do not avoid potentially lethal levels of urea on soil substrate. Environ Toxicol Chem 20:2328-2335

Jofre M, Karasov WH (1999) Direct effect of ammonia on three species of North American anuran amphibians. Environ Toxicol Chem 18:1806-1812

Lessels CM, Boag PT (1987) Unrepeatable repeatabilities: a common mistake. Auk 104:116-121

Lizana M, Ciudad MJ, Pérez-Mellado V (1989) Actividad, reproducción y uso del espacio en una comunidad de anfibios. Treballs de la Societat Catalana d́Ictiologia i Herpetología 2:92-127

Llorente GA, Arano B (1997) Rana perezi. In: Pleguezuelos JM (ed) Distribución y Biogeografía de los anfibios y reptiles en España y Portugal. Asociación Herpetológica Española-Universidad de Granada, Granada, pp 164-166

Llorente GA, Montori A, Carretero MA, Santos X (2002) Rana perezi In: Pleguezuelos JM, Márquez R, Lizana M (eds) Atlas y Libro Rojo de los anfibios y reptiles de España. Dirección General de Conservación de la Naturaleza-Asociación Herpetológica Española, Madrid, pp 126-128

Marco A, Cash D, Belden LK, Blaustein AR (2001) Sensitivity to urea fertilization in three amphibian species. Arch Environ Contam Toxicol 40:406-409 
Martín J, Luque-Larena JJ, López P (2006) Collective detection in escape responses of temporary groups of Iberian green frogs. Behav Ecol 17:222-226

Oldham RS, Latham DM, Hilton-Brown D, Towns M, Cooke AS, Burn A (1997) The effect of ammonium nitrate fertiliser on frog (Rana temporaria) survival. Agric Ecosyst Environ 61:69-74

Ortiz ME, Marco A, Saiz NI, Lizana M (2004) Impact of ammonium nitrate on growth and survival of six European amphibians. Arch Environ Cont Toxicol 47:234-239

Ortiz-Santaliestra ME, Marco A, Lizana M (2005) Sensitivity and behavior of the Iberian newt, Triturus boscai, under terrestrial exposure to ammonium nitrate. Bull Environ Contam Toxicol 75:662-669

Orton F, Can JA, Handy R (2006) Effects of nitrate and atrazine on larval development and sexual differentiation in the Northern leopard frog Rana pipiens. Environ Toxicol Chem 25:65-71

Ritter WF, Bergstrom L (2001) Nitrogen and water quality. In: Ritter WF, Shirmohammadi A (eds) Agricultural nonpoint source pollution: watershed management and hydrology. Lewis Publishers, Boca Ratón, pp 59-90

Schuytema GS, Nebeker AV (1999) Comparative effects of ammonium and nitrate compounds on Pacific treefrog and African clawed frog embryos. Arch Environ Contam Toxicol 36:200206

Statsoft (2001) STATISTICA (Data analysis software system) Version 6. StatSoft, Tulsa

Storfer A (2003) Amphibian declines: future directions. Div Dist 9:151-153

Stuart SN, Chanson JS, Cox NA, Young BE, Rodríguez ASL, Fischman DL, Waller RM (2004) Status and trends of amphibian declines and extinctions worldwide. Science 306:1783-1786

Vidal-Abarca MR, Montes R, Ramírez-Díaz L, Suárez ML (1987) El clima de la cuenca del Río Segura (S.E. de España): factores que lo controlan. Anales de Biología 12:11-28

Vidal-Abarca MR, Montes C, Suárez ML, Ramírez-Díaz L (1990) Sectorización ecológica de cuencas fluviales: aplicación a la cuenca del río Segura (SE España). Anales de Geografía de la Universidad Complutense 10:149-182

Vidal-Abarca MR, Suárez ML, Moreno JL, Gómez R, Sánchez I (2000) Hidroquímica de un río de características semiáridas (Río Chícamo; Murcia). Análisis espacio-temporal. Limnética 18:5773 